\title{
IMPACT OF THE HARD FACING TECHNOLOGY AND THE FILLER METAL ON TRIBOLOGICAL CHARACTERISTICS OF THE HARD FACED FORGING DIES
}

\author{
Dušan Arsić, Vukić Lazić, Ivan Samardžić, Ružica Nikolić, Srbislav Aleksandrović, Milan Djordjević, \\ Branislav Hadzima
}

Subject review

The forging dies are parts, which are operating at elevated temperatures, while simultaneously subjected to variable loads that can be compressive - even impact and shear. Impact of the hard facing technology is very strong since varying of the hard facing parameters directly affects the output characteristics of the hard faced layers. The criterion for estimating that impact was based on results of performed tribological investigations. The tribological parameters that were monitored were the friction coefficient, the wear scar/trace width and the wear area of the hard faced layers, with the two different types of lubricants. Hard facing technology implied selection of the welding process, filler metals, preheating temperatures and other parameters of the hard facing process. The influence of the proposed hard facing technology was determined by monitoring hardness, microstructure and wear resistance of the executed joints after the hard facing and after tempering. The objective of this work was to establish the correlation between the selected hard facing technology, filler metals and applied heat treatment on mechanical and tribological characteristics of the executed hard faced layers.

Keywords: forging dies; friction coefficient; hard facing; hardness; microstructure; wear resistance

Utjecaj tehnologije navarivanja i dodatnog materijala na tribološke karakteristike navarenih kovačkih alata

Pregledni članak

Kovački alati su dijelovi, koji rade na povišenim temperaturama, dok su istodobno izloženi promjenljivim opterećenjima, koja mogu biti tlačna - čak $\mathrm{i}$ udarna i smična. Utjecaj tehnologije navarivanja je vrlo jak, pošto se variranjem njegovih parametara direktno utječe na izlazne karakteristike navarenih slojeva. Kriterij za procjenu tog utjecaja bio je utemeljen na rezultatima obavljenih triboloških ispitivanja. Praćeni tribološki parametri bili su faktor trenja, širina traga (brazgotine) habanja kao i površina habanja navarenih slojeva, uz uporabu dva tipa maziva. Tehnologija navarivanja je podrazumijevala selekciju procesa zavarivanja, dodatnih materijala, temperature predgrijavanja i ostalih parametara procesa navarivanja. Utjecaj predložene tehnologije navarivanja je određivan praćenjem tvrdoće, mikrostrukture i otpornosti na habanje izvedenih spojeva, nakon navarivanja i nakon otpuštanja. Cilj ovog rada bio je uspostavljanje korelacija izabrane tehnologije navarivanja, dodatnih materijala i primijenjene toplinske obrade $s$ mehaničkim i tribološkim karakteristikama izvedenih navarenih slojeva.

Ključne riječi: faktor trenja; kovački alati; navarivanje; mikrostruktura; otpornost na habanje; tvrdoća

\section{Introduction}

The subject of this work was to determine the optimal reparatory technology by hard facing of the damaged forging dies based on tribological investigations of the performed test welds. Steels that are used for producing the forging dies must be able to sustain high impact loads, while simultaneously preserving the good mechanical properties. They also must be resistant to wear and thermal fatigue. That was the main research topic in [1]. Similar problems were considered in paper [2], namely an analysis was conducted of behaviour of a material deposited on the copper alloy. Thermal fatigue was also cause of failure of a tool for pressure casting analysed in [3] and analysis of crack appearance after certain number of cycles was done for the aluminium casting process. Besides the thermal fatigue, wear appears as the frequent cause of damages to this type of tools. The wear of forging dies, due to abrasion and adhesion, was the subject of research in [4], where the hard facing was applied as a method for recovery of the sustained damages. To extend the service life of the forging dies, their wear was analysed numerically in [5] during the final phase of forging. By comparing the numerical results with the measurements taken from the worn die, the wear coefficient has been evaluated for different points of the die surface and finally a value of wear coefficient is suggested.
Paper [6] represents the first part of investigation of this group of authors, related to prescribing the optimal reparation technology of the forging dies by hard facing. In [6] the optimal technology was considered based on criterion of the cooling time between 800 and $500{ }^{\circ} \mathrm{C}, t_{8 / 5}$, for the same steels that are considered in this paper (proposed hard facing technology is described in details in ref. [6], so presenting of certain data about it is avoided in this paper).

Alloyed steels are usually used for producing the forging dies. They do not possess very good weldability. Any hard facing reparation of pieces made of those steels requires specially prescribed technology, adjusted to that piece, since certain alloying increases proneness of those steels to self-hardening $[7 \div 9]$. Some authors have also dealt with hard facing of alloys like Inconel and Stellites, investigating the prescribed technologies and selected filler metals. Those materials harden during operation and thus they increase strength and resistance to wear and impact loads. Alloys Inconel 625 and Stellite 21 had the best wear resistance $[8,9]$. Besides the optimal hard facing technology and selection of filler metals $[9,10]$, it is necessary to define the adequate heat treatment before, during and after the welding $[11 \div 13]$. Resulting welds, after the hard facing and the final heat treatment, were tested in tribological conditions, to establish their wear resistance, as well as by destructive methods to obtain the hardness distribution in the cross section, 
microstructure of the hard faced layer, heat affected zone (HAZ) and the base metal (BM).

\section{Tools materials' properties, selection of the filler metals, welding procedure and its parameters}

Steels used for hard facing were 56NiCrMoV7 and X38CrMoV51 (by DIN 17350). Chemical composition and mechanical properties of those steels, the details of the proposed hard facing technological parameters and chemical composition of used filler metals are given in [6]. The adopted preheating temperature was $T_{\mathrm{p}} \approx 300{ }^{\circ} \mathrm{C}$, calculated according to Seferian's formula [9]. The layers were deposited by the MMA welding procedure in two or three passes due to necessity to reduce the degree of dilution - to obtain the declared weld properties prescribed by the electrodes manufacturers [6]. The hard facing speed was measured for each pass with Tastotherm D1200 (measurements range of -50 to $1200^{\circ} \mathrm{C}$ ).

The two high-alloyed rutile electrodes, UTOP 38 and UTOP 55, were used as the filler metals (FM) [6]. Those filler metals are intended for hard facing of tools, for cold and hot forming of steels and other metals. The hardness of hard faced layers, executed by those electrodes, should be stable up to temperature of $600{ }^{\circ} \mathrm{C}$. Prior to hard facing, electrodes were dried up to $350 \div 400{ }^{\circ} \mathrm{C}$. That caused a decrease of the diffused hydrogen and elimination of cold cracks appearance.

The hard faced layer deposition order is shown in Fig. 1 in [6]. Prior to depositing the next layer, the slag was removed from the previous one by the steel brush. The width of the pass deposited by the electrode of diameter $\varnothing 3,25 \mathrm{~mm}$ was $b \approx 10 \div 12 \mathrm{~mm}$, the height was $h \approx 1,5 \mathrm{~mm}$. For the electrode of diameter $\varnothing 5,00 \mathrm{~mm}$ parameters were $b \approx 10 \div 12 \mathrm{~mm}$ and $h \approx 2,1 \mathrm{~mm}$.

\section{Experimental investigations}

During the experimental investigations the following tests were performed: measurements of hardness and reading-off the microstructure of the characteristic zones of the executed hard faced layers and the tribological tests for determination of the friction coefficient and the wear scar width.

\subsection{Investigations of hardness and microstructure}

The metallographic samples - slits were prepared by grinding, from plates that were hard faced in various conditions (Fig. 1). The samples/plate thickness varied between 7,4 $\mathrm{mm}$ and $29 \mathrm{~mm}$. The filler metals and their diameters were also varied, as well as other parameters of the hard facing procedure. Samples were cooled in fireclay powder, and prior to metallographic tests, they were heated together with the furnace to the tempering temperature $T_{\text {temp }}=340{ }^{\circ} \mathrm{C}$ and then slowly cooled to reduce the level of residual stresses. The hardness distribution diagrams are presented in Figs. 2 and 3, for the BM 56NiCrMoV7 and two types of filler metals and two plate thicknesses. In both cases, samples were preheated to $T_{\mathrm{p}}=300{ }^{\circ} \mathrm{C}$, and after the hard facing tempered at $T_{\text {temp }}=340{ }^{\circ} \mathrm{C}$ [9]. The hardness measurement was done according to appropriate standard [17].

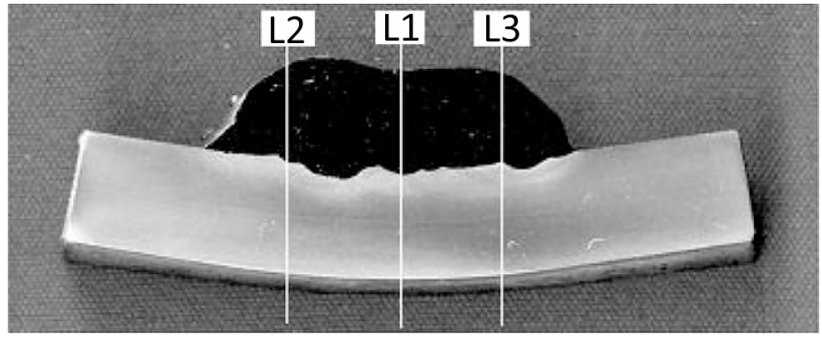

Figure 1 Sample for measuring hardness and investigating the microstructure

Obtained results (Figs. 2 and 3) show that in both cases the hard faced layer had significantly higher hardness than the base metal. From diagrams one can also notice the influence of the prescribed tempering after the hard facing. The hardness of the hard faced layer decreases, but it is still for about $100 \mathrm{HV} 1$ higher than that of the base metal, what was the intended objective.

\subsection{Tribological investigations - wear resistance estimate}

Tribological investigations were done at the Faculty of Engineering in Kragujevac on tribometer TR-95. The topography of the pin and disk surfaces was measured on the computer measuring system Talysurf 6 and the wear scar width was measured on the universal microscope UIM-21, with magnification of $50 \times$. The aim of those investigations was to determine resistance of the BM to wear, as well as of the deposited coatings - the hard faced layers.

\subsubsection{Tribological investigations with lubricant LM 76}

The contact (block on disc) was realized with variation of the normal force $\left(F_{\mathrm{N}}=100,150,200\right.$ and 250 $\mathrm{N})$, and the sliding speed $\left(v_{\mathrm{sl}}=1,5 ; 2,0\right.$ and $\left.2,5 \mathrm{~m} / \mathrm{s}\right)$. These measurements, performed during the running-in period of approximately $6 \mathrm{~min}$, enabled determination of the friction coefficient and thus the friction force. Then, the normal force $F_{\mathrm{N}}=250 \mathrm{~N}$ was adopted with the sliding speed $v_{\mathrm{sl}}=2 \mathrm{~m} / \mathrm{s}$, and during the contact period of approximately $30 \mathrm{~min}$ the friction coefficient variation was registered (Figs. 4, 5 and 6). When the contact stopped, the topography of the pin and disk surfaces was measured, i.e., the wear scar width of the pin was determined (Fig. 7). The wear scar width was measured using a universal microscope $[14 \div 16]$.

Based on those investigations, it can be noticed that significantly higher resistance to wear was exhibited by the hard faced layers with respect to the base metal (especially those deposited by the UTOP 55 electrode, which points to a complexity of the selecting procedure of the filler metals aimed for real technological working conditions of the forging dies). 


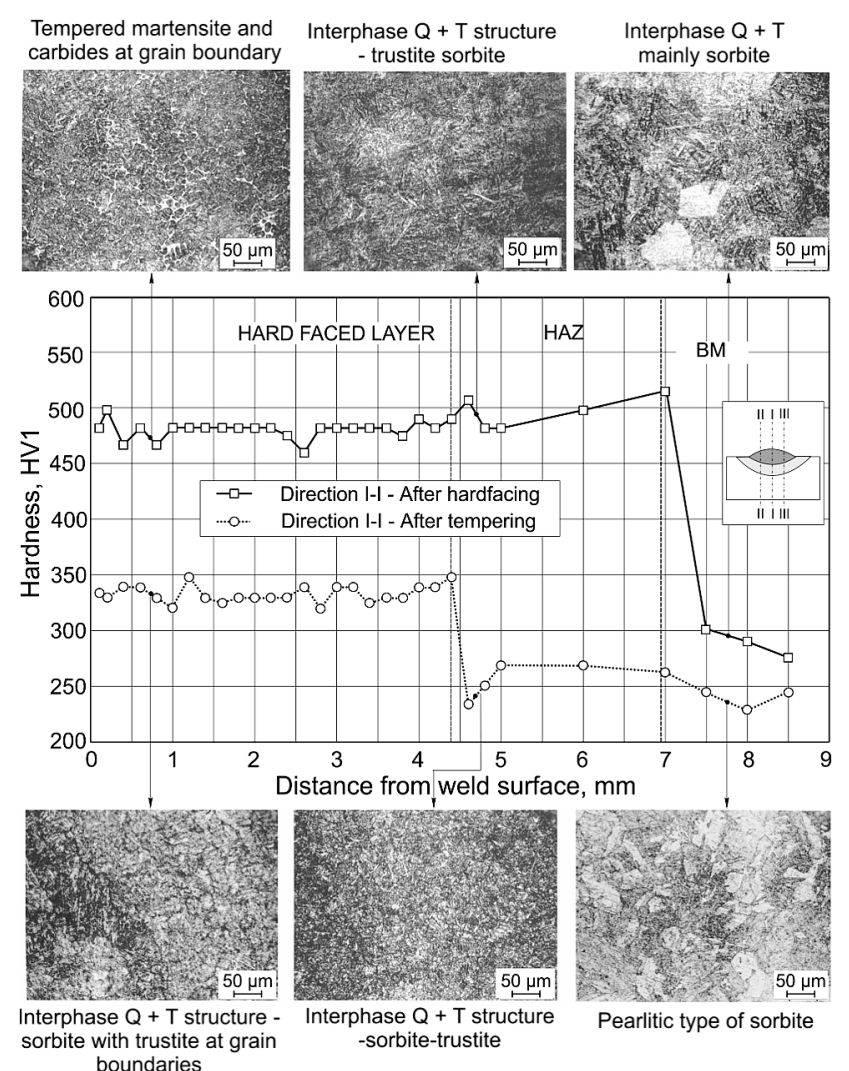

Figure 2 Hardness distribution and microstructure of the hard faced layer zones (FM, Electrode UTOP $38-s=7,4 \mathrm{~mm}$ )

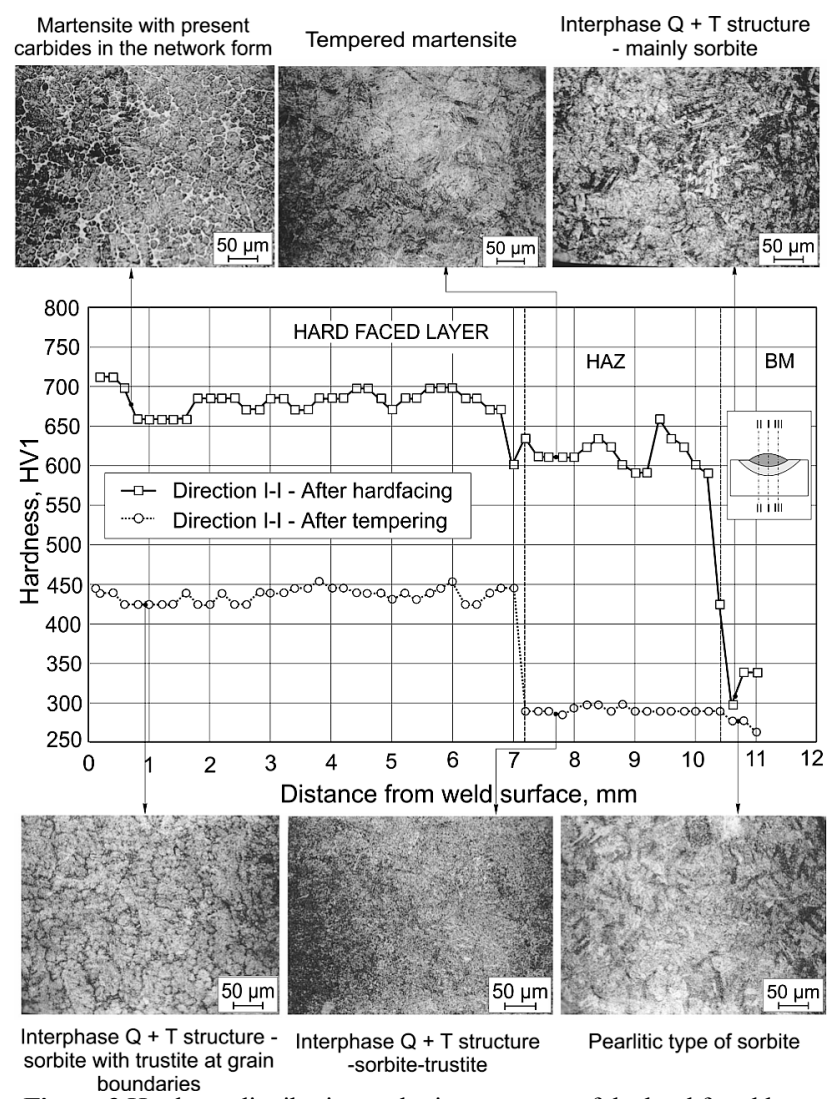

Figure 3 Hardness distribution and microstructure of the hard faced layer zones (FM, Electrode UTOP $55-s=29 \mathrm{~mm}$ )

Fig. 8 gives the average variation of the friction coefficient after the conducted tests, and Fig. 9 shows the average value of the wear scar width for different pins. The results of those investigations show that the hard faced layers exhibit a significantly higher resistance to wear than the base metals, which justifies hard facing of the damaged working surfaces of dies and tools (if performed by using the filler metals proper for real working conditions e.g. UTOP $55[14 \div 16])$.

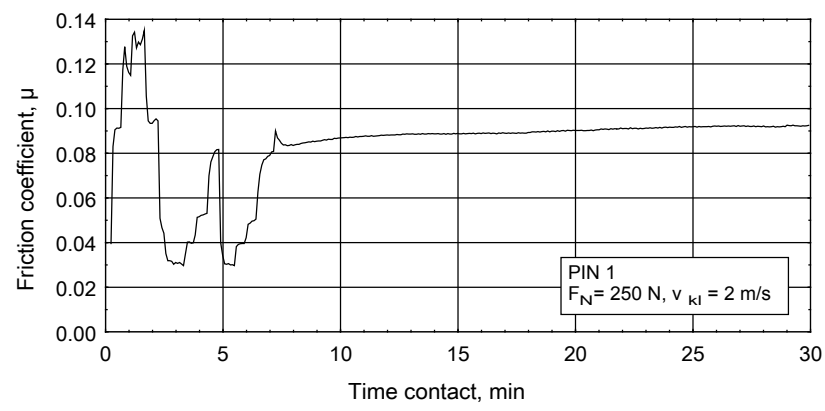

Figure 4 The friction coefficient variation with time: (FM - X38CrMoV51 - UTOP 38 - 3 layers)

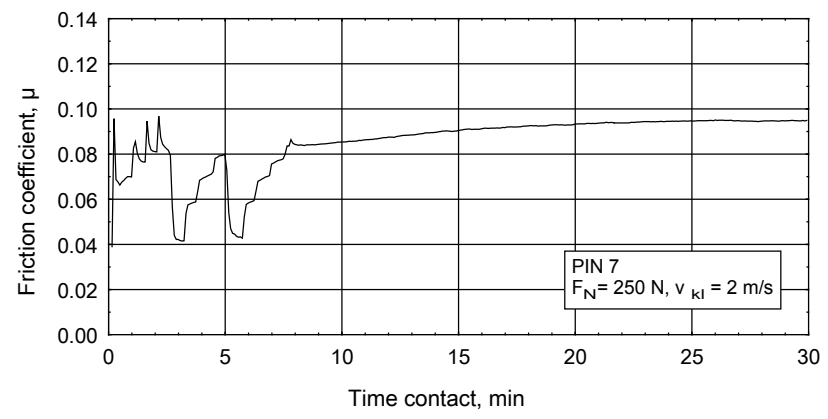

Figure 5 The friction coefficient variation with time: (FM - X38CrMoV51 - UTOP 55 - 3 layers)

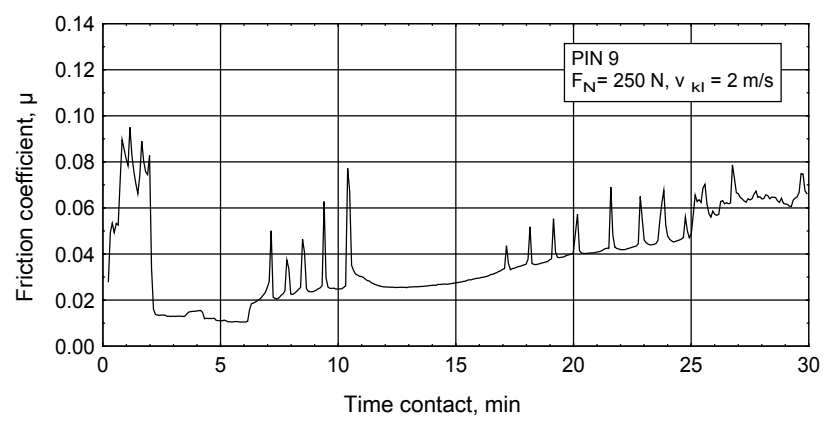

Figure 6 Friction coefficient variation with time: (BM - 56NiCrMoV7)

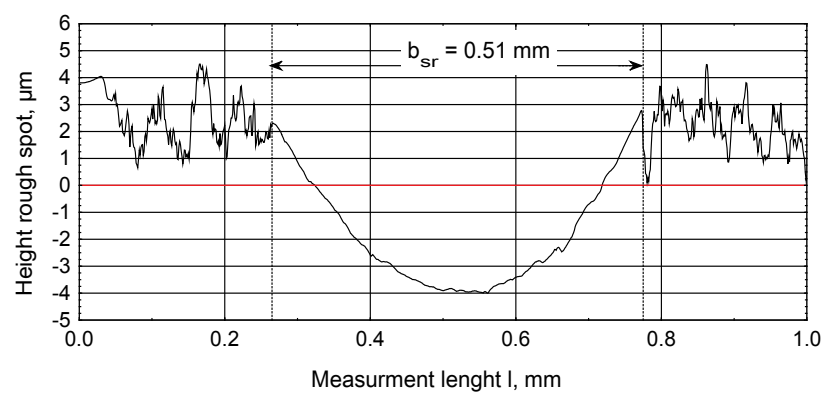

Figure 7 Layout of the wear scar - PIN No. 7, contact period of 30 minutes

After the tribological investigations, the analyses of macroscopic, as well as of microscopic damages, were done. Figs. 10a, 10b and 10c show some typical pin damages. 


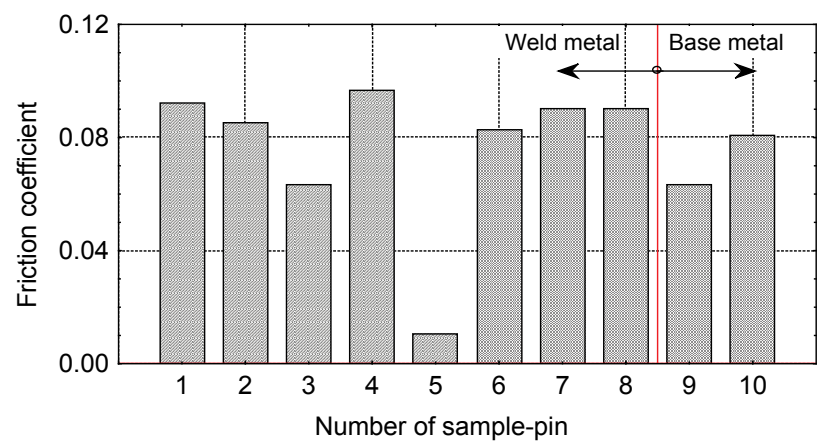

Figure 8 The friction coefficient after the 30 minutes contact (lubricant LM 76)

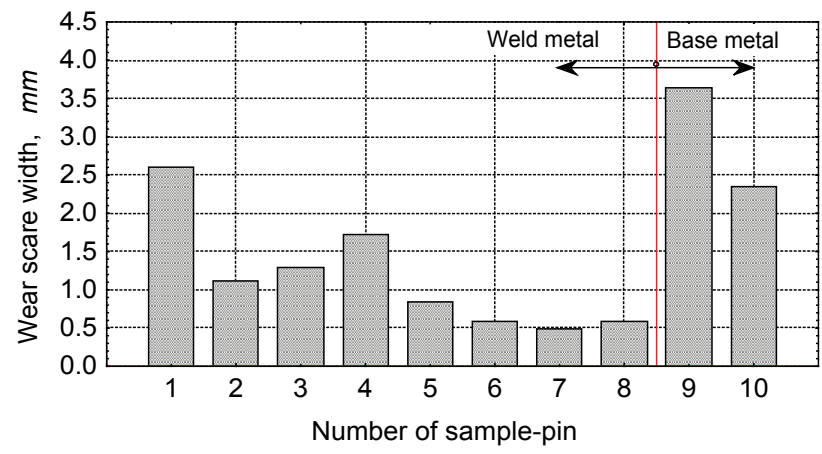

Figure 9 The wear scar width after the 30 minutes contact time (lubricant LM 76)
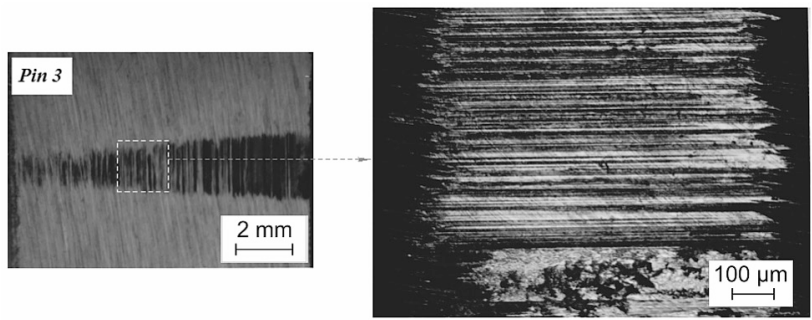

a) Pin 3 - F.M. - UTOP 38
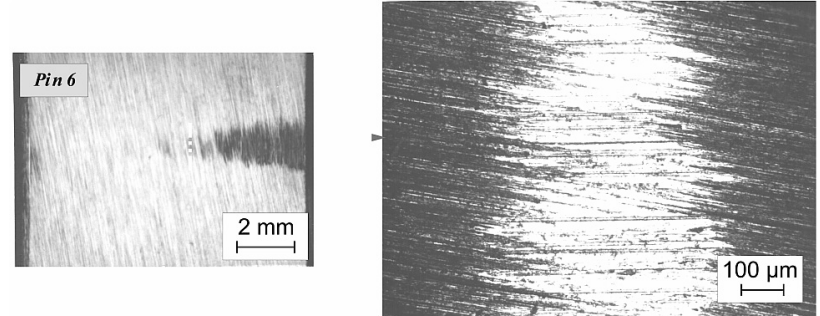

b) Pin 6 - F.M. - UTOP 55
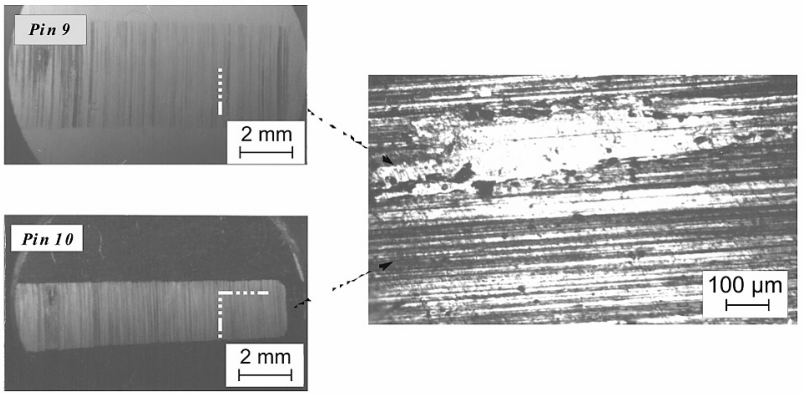

c) Pins 9 and 10 - B.M. - 56NiCrMoV7 and X38CrMoV51 Figure 10 Wear of the certain pins

\subsubsection{Tribological investigations with lubricant LM $76+6 \%$ MoS $_{2}$ applied}

Based on the manufacturer's claims [16], the lubricant LM $76+6 \% \mathrm{MoS}_{2}$ can reduce wear by $50 \%$ while keeping good lubricating properties at a wide temperature range. Therefore, this lubricant is better than graphite grease because it can be used for lubrication at temperatures from -45 to $400{ }^{\circ} \mathrm{C}$. The results of these tribological investigations are shown in Figs. 11 to 14 [16].

After the tribological tests with the new lubricant had been carried out, macroscopic and microscopic damages of the pins were analysed. Figs. 15a and 15b show those pins' damages. The analysed wear scars are significantly less pronounced than in the case when the pure lubricant LM 76 (Figs. 15a and 15b) was applied, which agrees with the measured wear scar widths [16].

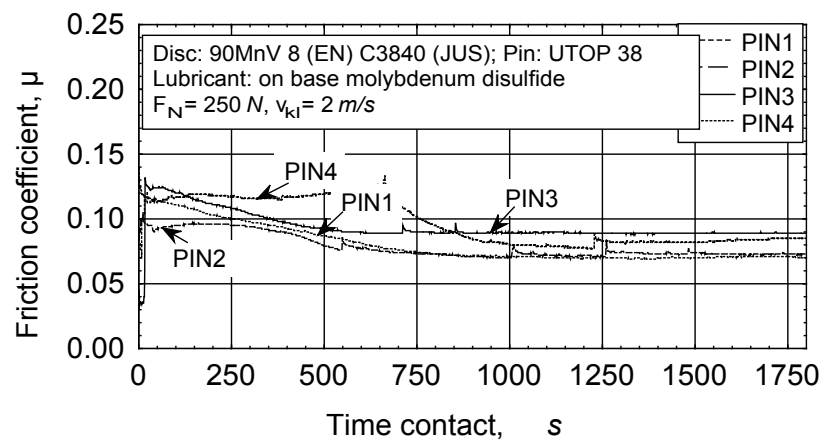

a)

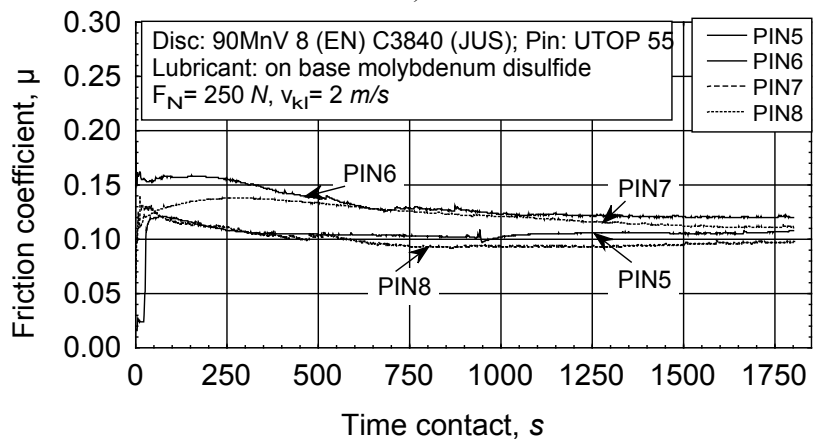

b)

Figure 11 Change of the friction coefficient during the contact period of 30 min: a) UTOP 38 , b) UTOP 55

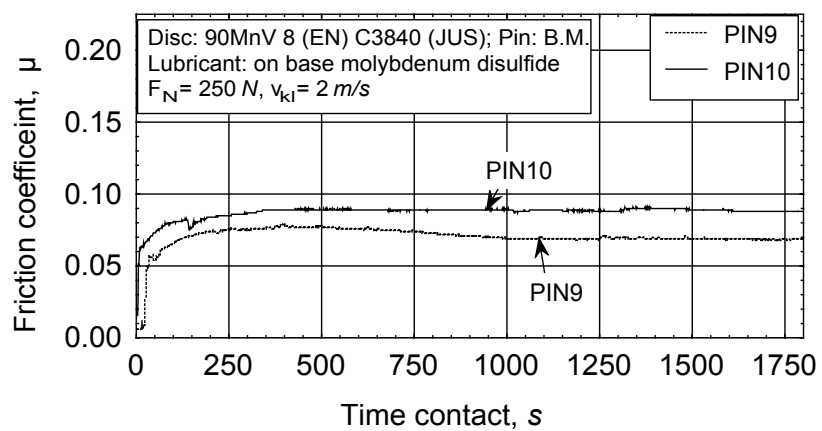

Figure 12 Change of the friction coefficient during the contact period of $30 \mathrm{~min}$

Finally, the tribological investigations have shown that the hard faced layers are much more resistant to wear compared to the base metal, but from the aspect of energy the base metal has better properties. The experiments performed in order to determine the friction forces, the friction coefficient and the wear scar width for pins of different properties (hardness, microstructure), show that with an increase in the pin hardness, the friction coefficient increases and the wear scar width decreases. 


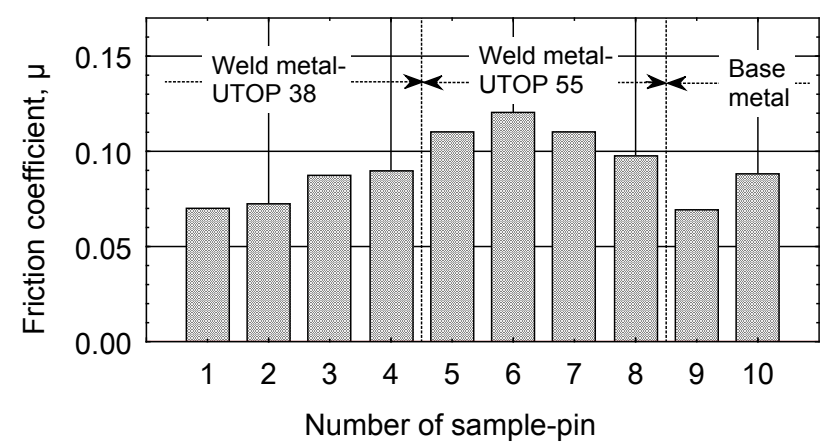

Figure 13 The friction coefficient after the 30 minutes contact time (lubricant LM 76+6\% $\mathrm{MoS}_{2}$ )

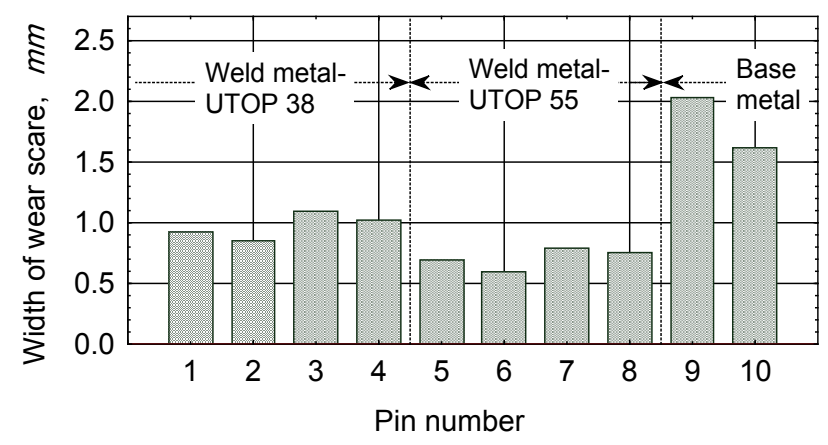

Figure 14 The wear scar width after the 30 minutes contact time (lubricant LM 76+6\% $\mathrm{MoS}_{2}$ )
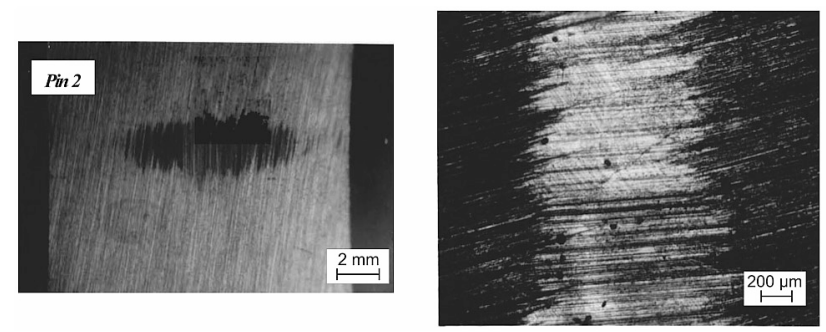

a) PIN No. 2 - lubricant with $6 \% \mathrm{MoS}_{2}$ - F.M. - UTOP 38
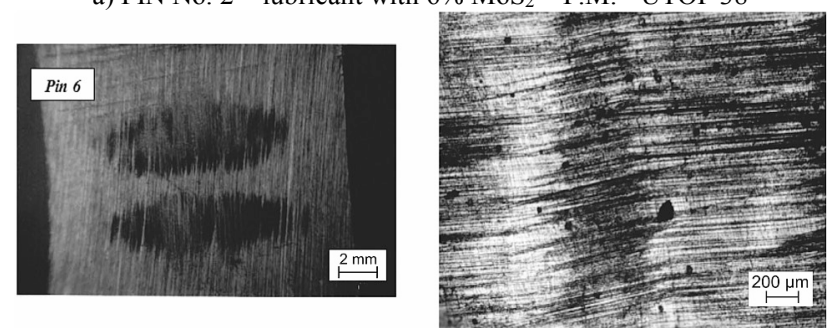

b) Pin 6 - lubricant with $6 \% \mathrm{MoS}_{2}$ - F.M. - UTOP 55

Figure 15 Wear of the certain pins

The wear area is the narrowest in the layer hard faced using a UTOP 55 electrode, a little wider in the layers hard faced using a UTOP 38 electrode, and the widest on the base metal. Increased wear on the contact area between the tool and the work piece leads to an increase of energy needed for deformation. The quality of different lubricants, normally used for hot forging, was also evaluated in these experiments. Conducted tribological investigations show that the working life of the hard faced dies can exceed the working life of the new dies.

\section{Conclusions}

An attempt to establish the impact of the hard facing technology on mechanical and tribological characteristics of the hard faced forging dies was done in this paper. The monitored parameters were hardness in all the zones of the hard faced layers, the friction coefficient and wear scar width. Additional tempering of the hard faced layers has led to lowering the hardness and the residual stresses and to change in microstructure. The phase transformation of martensite into the more stable structures - sorbite and trustite occurred, due to tempering, what is more favourable from the aspect of dynamical durability.

Several main objectives were achieved by application of the proposed hard facing technology:

1) Hardness of the hard faced layer was higher than that of the base metal - about 500 HV1 for the UTOP 38 and about $700 \mathrm{HV} 1$ for the UTOP 55 and

2) Hardness in the HAZ, as the most critical zone of the hard faced layer, was reduced by tempering (prior to heat treatment it was equal to BM hardness).

3) It was established which filler metal is the optimal for hard facing of the damaged forging dies and what were the hard faced layers characteristics after application of each of them.

4) Tribological investigations also confirmed that the hard faced layers of certain samples (pin 5, Fig. 8) have the lower friction coefficient than the base metal, and that all of them have significantly higher wear resistance with respect to the base metal (Fig. 8). The wear scar width of hard faced pins was $1 \mathrm{~mm}$ on average, versus $3 \mathrm{~mm}$ that was measured on the base metal.

5) In the case when different lubricants were applied, it was established that the lower friction coefficient and significantly narrower wear scar were obtained when the lubricant LM 76 with $6 \% \mathrm{MoS}_{2}$ is applied. A more uniform change of the friction coefficient was also noticed both for the hard faced layer and for the base metal. The change of the friction coefficient was especially uniform at pins 9 and 10 (Fig. 13), where the change of this coefficient was occasionally abrupt when the lubricant LM 76 was applied. An increased efficiency of the new lubricant is explained by the essential role of the molybdenum-disulphide, which has a hexagonal structure with atoms of $\mathrm{S}$ and Mo arranged in layers on the crystal lattice. Those layers slide easily over one another so that the lubricant layer is difficult to break through. Fig. 14 shows that UTOP 55 is more favourable for forging dies hard facing.

\section{Acknowledgements}

This research was partially financially supported by the Ministry of Education, Science and Technological development of Republic of Serbia through project TR 35024 and by European regional development fund and Slovak state budget by the project "Research Center of the University of Žilina" - ITMS 26220220183. The authors are very grateful for this funding.

\section{References}

[1] Jhavar, S.; Paul, C. P.; Jain, N. K. Causes of failure and repairing options for dies and moulds: A review. // Engineering Failure Analysis. 34, (2013), pp. 519-535. DOI: 10.1016/j.engfailanal.2013.09.006 
[2] Imran, M. K.; Masood, S. H.; Brandt, M.; Bhattacharya, S.; Gulizia, S.; Jahedi, M.; Mazumder, J. Thermal fatigue behavior of direct metal deposited H13 tool steel coating on copper alloy substrate. // Surface \& Coatings Technology. 206, (2012), pp. 2572-2580. DOl: 10.1016/j.surfcoat.2011.11.016

[3] Lavtar, L.; Muhic, T.; Kugler, G.; Tercelj, M. Analysis of the main types of damage on a pair of industrial dies for hot forging car steering mechanisms. // Engineering Failure Analysis. 18, (2005), pp. 1143-1152. DOl: 10.1016/j.engfailanal.2010.11.002

[4] Kohopaa, J.; Hakonen, H.; Kivivuori, S. Wear resistance of hot forging tools surfaced by welding. // Wear. 130, (1989), pp. 103-112. DOI: 10.1016/0043-1648(89)90225-1

[5] Abachi, S.; Akkok, M.; Gokler, M. I. Wear analysis of hot forging dies. // Tribology International. 43, (2010), pp. 467473. DOI: 10.1016/j.triboint.2009.07.011

[6] Arsić, D.; Lazić, V.; Nikolić, R. R.; Sedmak, A.; Aleksandrović, S.; Djordjević, M.; Bakić, R. Selection of the optimal hard facing (HF) technology of damaged forging dies based on cooling time $t_{8 / 5}$. // Metallurgy. 55, 1(2016), 103-106.

[7] Kashani, H.; Amadeh, A.; Ghasemi, H. M. Room and high temperature wear behaviors of nickel and cobalt base weld overlay coatings on hot forging dies. // Wear. 262, (2007), pp. 800-806. DOI: 10.1016/j.wear.2006.08.028

[8] Fouillanda, L.; El Mansoria, M.; Massaq, A. Frictioninduced work hardening of cobalt-base hard facing deposits for hot forging tools. // Journal of Materials Processing Technology. 209, (2009), pp. 3366-3373. DOI: 10.1016/j.jmatprotec.2008.07.039

[9] Mutavdžić, M.; Čukić, R.; Jovanović, M.; Milosavljević, D.; Lazić, V. Model investigations of the filler materials for regeneration of the damaged parts of the construction mechanization. // Tribology in Industry. 30, 3 (2008), pp. 3-9.

[10] Marković, S.; Milović, LJ.; Marinković, A.; Lazović, T. Tribological aspect of selecting filler metal for repair surfacing of gears by hard facing. // Structural Integrity and Life. 11, 2(2011), pp. 127-130.

[11] Mutavdžić, M.; Lazić, V.; Milosavljević, D.; Aleksandrović, S.; Nikolić, R.; Čukić, R. Determination of the optimal tempering temperature in hard facing of the forging dies. // Materials Engineering. 19, 3(2012), pp. 95103.

[12] Ghosh, A.; Barman, N.; Chattopadhyay, H.; Hloch, S. A study of thermal behaviour during submerged arc welding. // Strojniski Vestnik - Journal of Mechanical Engineering. 59, 5(2013), pp. 333-338.

[13] Vegelj, D.; Zajec, B.; Gregorčič, P.; Možina, J. Adaptive pulsed-laser welding of electrical laminations. // Strojniski Vestnik - Journal of Mechanical Engineering. 60, 2(2014), pp. 106-114.

[14] Lazić, V.; Sedmak, A.; Aleksandrović, S.; Milosavljević, D.; Čukić, R.; Grabulov, V. Reparation of damaged mallet for hammer forging by hard facing and weld cladding. // Tehnicki vjesnik-Technical Gazette. 16, 4(2009), pp. 107113.

[15] Lazić, V.; Mutavdžić, M.; Milosavljević, D.; Aleksandrović, S.; Nedeljković, B.; Marinković, P.; Čukić, R. Selection of the most appropriate technology of reparatory hard facing of working parts on universal construction machinery. // Tribology in Industry. 33, 1(2011), pp. 18-27.

[16] Lazić, V.; Milosavljević, D.; Aleksandrović, S.; Marinković, P.; Bogdanović, G.; Nedeljković, B.; Mutavdžić, M. Tribological investigations of hard faced layers and base metals of forging dies with different kinds of lubricants applied. // Tribology in industry. 32, 4(2010), pp. $36-44$.

[17] ISO 6507-1:2005 Metallic materials - Vickers hardness test - Part 1: Test method.

\section{Authors' addresses \\ Dušan Arsić, research associate \\ Faculty of Engineering, University of Kragujevac Sestre Janjic 6, 34000 Kragujevac, Serbia \\ E-mail: dusan.arsic@fink.rs}

\section{Vukić Lazić, full professor}

Faculty of Engineering, University of Kragujevac Sestre Janjic 6, 34000 Kragujevac, Serbia

E-mail: vlazic@kg.ac.rs

\section{Ivan Samardžić, full professor}

Mechanical Engineering Faculty in Slavonski Brod, Josip Juraj Strossmayer University of Osijek,

Trg Ivane Brlić-Mažuranić 2, 35000 Slavonski Brod, Croatia E-mail: Ivan.Samardzic@sfsb.hr

\section{Ružica R. Nikolić, full professor}

Faculty of Engineering, University of Kragujevac Sestre Janjic 6, Kragujevac, Serbia

Research Center, University of Žilina Univerzitna 1, 01026 Žilina, Slovakia

E-mail: ruzicarnikolic@yahoo.com

\section{Srbislav Aleksandrović, full professor}

Faculty of Engineering, University of Kragujevac Sestre Janjic 6, 34000 Kragujevac, Serbia E-mail: omdlab@kg.ac.rs

\section{Milan Djordjević, research associate}

Faculty of Engineering, University of Kragujevac Sestre Janjic 6, 34000 Kragujevac, Serbia E-mail: tpolab@fink.rs

Branislav Hadzima, professor, Director

Research Center, University of Žilina Univerzitna 1, 01026 Žilina, Slovakia E-mail: branislav.hadzima@rc.uniza.sk 